\title{
Article \\ Molecular Mechanisms and Tumor Biological Aspects of 5-Fluorouracil Resistance in HCT116 Human Colorectal Cancer Cells
}

\author{
Chinatsu Kurasaka ${ }^{1}$, Yoko Ogino ${ }^{1,2}$ and Akira Sato ${ }^{1, *(D)}$ \\ 1 Department of Biochemistry and Molecular Biology, Faculty of Pharmaceutical Sciences, Tokyo University \\ of Science, 2641 Yamazaki, Noda, Chiba 278-8510, Japan; 3a16042@ed.tus.ac.jp (C.K.); ogino@rs.tus.ac.jp (Y.O.) \\ 2 Department of Gene Regulation, Faculty of Pharmaceutical Sciences, Tokyo University of Science, \\ 2641 Yamazaki, Noda, Chiba 278-8510, Japan \\ * Correspondence: akirasat@rs.tus.ac.jp; Tel.: +81-4-7121-3620
}

Citation: Kurasaka, C.; Ogino, Y.; Sato, A. Molecular Mechanisms and Tumor Biological Aspects of 5-Fluorouracil Resistance in HCT116 Human Colorectal Cancer Cells. Int. J. Mol. Sci. 2021, 22, 2916. https://doi.org/10.3390/ijms22062916

Academic Editor: Valentina De Falco

Received: 1 February 2021

Accepted: 10 March 2021

Published: 13 March 2021

Publisher's Note: MDPI stays neutral with regard to jurisdictional claims in published maps and institutional affiliations.

Copyright: (c) 2021 by the authors. Licensee MDPI, Basel, Switzerland. This article is an open access article distributed under the terms and conditions of the Creative Commons Attribution (CC BY) license (https:/ / creativecommons.org/licenses/by/ $4.0 /)$.

\begin{abstract}
Fluorouracil (5-FU) is a cornerstone drug used in the treatment of colorectal cancer (CRC). However, the development of resistance to 5-FU and its analogs remain an unsolved problem in CRC treatment. In this study, we investigated the molecular mechanisms and tumor biological aspects of 5-FU resistance in CRC HCT116 cells. We established an acquired 5-FU-resistant cell line, HCT116R ${ }^{\mathrm{F} 10}$. HCT116R ${ }^{\mathrm{F} 10}$ cells were cross-resistant to the 5-FU analog, fluorodeoxyuridine. In contrast, HCT116 $\mathrm{R}^{\mathrm{F} 10}$ cells were collaterally sensitive to SN-38 and CDDP compared with the parental HCT16 cells. Whole-exome sequencing revealed that a cluster of genes associated with the 5-FU metabolic pathway were not significantly mutated in HCT116 or HCT116R ${ }^{\text {F10 }}$ cells. Interestingly, $\mathrm{HCT} 116 \mathrm{R}^{\mathrm{F} 10}$ cells were regulated by the function of thymidylate synthase (TS), a 5-FU active metabolite 5-fluorodeoxyuridine monophosphate (FdUMP) inhibiting enzyme. Half of the TS was in an active form, whereas the other half was in an inactive form. This finding indicates that 5-FU-resistant cells exhibited increased TS expression, and the TS enzyme is used to trap FdUMP, resulting in resistance to 5 -FU and its analogs.
\end{abstract}

Keywords: colorectal cancer cells; drug resistance; 5-Fluorouracil; thymidylate synthase; exome sequencing

\section{Introduction}

Colorectal cancer (CRC) is the third-most common cancer in the world [1], and 5Fluorouracil (5-FU) is the most important chemotherapeutic agent used in its treatment $[2,3]$. 5-FU is also widely used to treat other cancers, such as gastric, pancreatic, breast, ovarian, and head and neck cancers [2,3]. 5-FU is converted to 5-fluorodeoxyuridine monophosphate (FdUMP), which is a potent inhibitor of thymidylate synthase (TS) [3-5]. FdUMP forms a covalent complex with TS in the presence of 5,10-methylenetetrahydrofolate $\left(\mathrm{CH}_{2}-\mathrm{THF}\right)[2,3,5]$. The inhibition of TS depletes the intracellular dTTP pool and subsequently inhibits DNA synthesis [2-5]. Another effect by which 5-FU can exert its cytotoxic action is its incorporation as fluorodeoxyuridine triphosphate (FdUTP) and fluorouridine triphosphate (FUTP) into DNA and RNA, respectively [2-4]. Experimental and clinical studies indicate that continuous exposure of CRC cells to 5-FU results in acquired resistance to 5-FU and its derivatives. This is often caused by common cancer resistance mechanisms, such as drug inactivation, drug efflux, drug target alterations, bypass pathway activation, DNA damage repair, and cell death [2,3]. 5-FU resistance is correlated with the level of TS protein and enzymatic activity in cancer cells [2,3,6-8]. In addition, high TS protein and RNA expression levels in tumor tissue is also a useful biomarker for poor prognosis for 5-FU-based chemotherapy in CRC patients [2,3,9]. Furthermore, 5-FU sensitivity is influenced by the expression levels of dihydropyrimidine dehydrogenase (DPD) [9,10], which converts 5-FU 
to dihydrofluorouracil (DHFU) during the catabolic process $[2-4,9,10]$. However, 5-FU resistance has not yet been circumvented clinically.

In this study, we established a 5-FU-resistant HCT116 CRC cell line (HCT116R ${ }^{\mathrm{F} 3}$ and HCT116 ${ }^{\mathrm{F} 10}$ ) and analyzed its biological features. HCT116R ${ }^{\mathrm{F} 10}$ cells, which are crossresistant to the 5-FU analog fluorodeoxyuridine (FUdR), were collaterally sensitive to SN-38 and CDDP compared with the parental HCT16 cells. In addition, HCT116R ${ }^{\mathrm{F} 10}$ cells exhibited a lower ability to form tumor spheres compared with parental HCT116 cells. Notably, HCT116R ${ }^{\mathrm{F} 10}$ cells maintained the tumor sphere formation ability compared with HCT116 cells under 5-FU exposure conditions. Furthermore, a gene cluster associated with 5-FU metabolic pathway was not significantly mutated in HCT116 and HCT116R ${ }^{\mathrm{F} 10}$

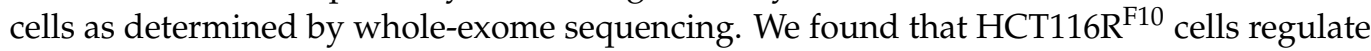
intracellular TS states in which half of the TS enzyme is in a functional form and the other half exists as an FdUMP-covalent complex (inactive form). These findings provide a better understanding of resistance to anticancer 5-FU and its analogs.

\section{Results}

\subsection{Establishment of the 5-Fluorouracil-Resistant HCT116 Cells}

To elucidate the mechanisms underlying resistance to 5-FU, we generated a variant of the HCT116 human colorectal cancer cell line that was resistant to 5-FU, an important anticancer drug used for CRC treatment [2,3]. We established 5-FU-resistant HCT116R ${ }^{\mathrm{F} 3}$ or HCT116R ${ }^{\mathrm{F} 10}$ cells by repeated exposure of parental HCT116 cells to stepwise increasing concentrations of 5-FU over a period of approximately 12 weeks at $3 \mu \mathrm{M}$ and 14 weeks at

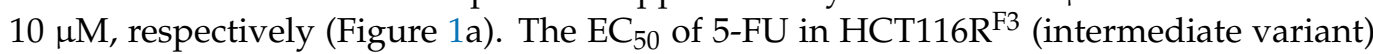
and HCT116 ${ }^{\mathrm{F} 10}$ cells were determined by a WST- 8 assay after continuous exposure for $72 \mathrm{~h}$. As shown in Table 1 and Figure $1 \mathrm{~b}$, the $\mathrm{EC}_{50}$ value of the 5-FU-resistant HCT11 6 cells was higher $\left(1.5 \times 10^{-5} \mathrm{M}\right.$ in HCT116R ${ }^{\mathrm{F} 3}$ and $2.9 \times 10^{-5} \mathrm{M}$ in HCT116R $\mathrm{R}^{\mathrm{F} 10}$ cells $)$ than that of sensitive, parental HCT116 cells $\left(5.1 \times 10^{-6} \mathrm{M}\right)$. The RI was approximately 2.9 for $\mathrm{HCT}_{116 \mathrm{R}^{\mathrm{F}} 3}$ cells and 5.7 for HCT116 $\mathrm{R}^{\mathrm{F} 10}$ cells (Table 1). In addition, similar results were obtained by colony formation assay (Figure 1c,d). The $\mathrm{EC}_{50}$ value of 5-FU-resistant HCT116 cells was significantly higher $\left(1.6 \times 10^{-5} \mathrm{M}\right.$ in HCT116 $\mathrm{R}^{\mathrm{F} 3}$ and $3.8 \times 10^{-5} \mathrm{M}$ in HCT116 $\mathrm{R}^{\mathrm{F} 10}$ cells) than that of the parental HCT116 cells $\left(5.5 \times 10^{-6} \mathrm{M}\right)$ (Table 1). The RI of HCT116 $\mathrm{R}^{\mathrm{F} 3}$ and HCT116R $\mathrm{R}^{\mathrm{F} 10}$ cells was approximately 2.9 and 6.9 , respectively (Table 1). Furthermore, parental HCT116, HCT116R ${ }^{\mathrm{F} 3}$, and HCT116R ${ }^{\mathrm{F} 10}$ cells exhibited nearly similar morphological features (Figure 1e).

(a)

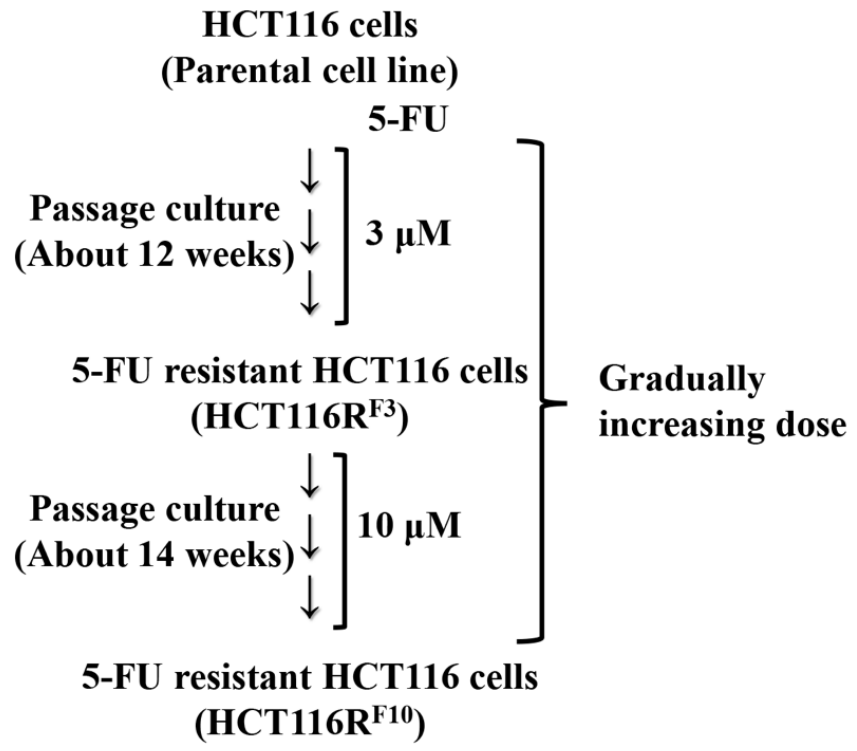

(b)

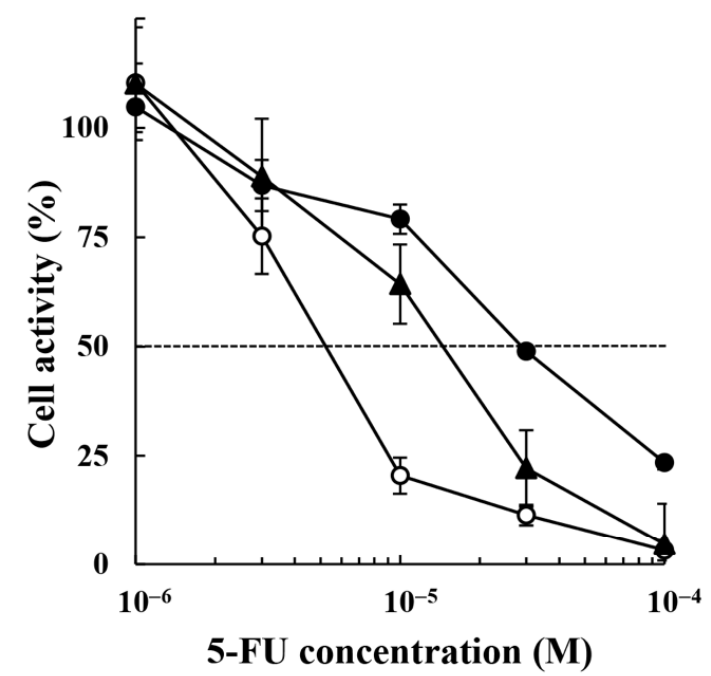

Figure 1. Cont. 
(c)

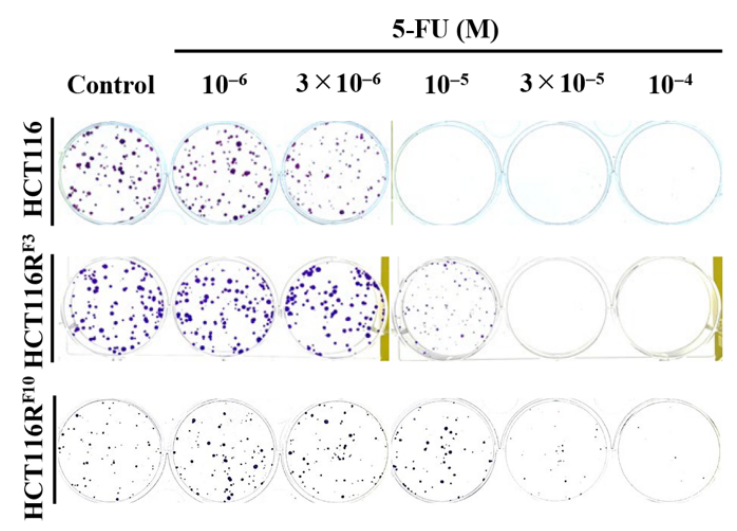

(d)

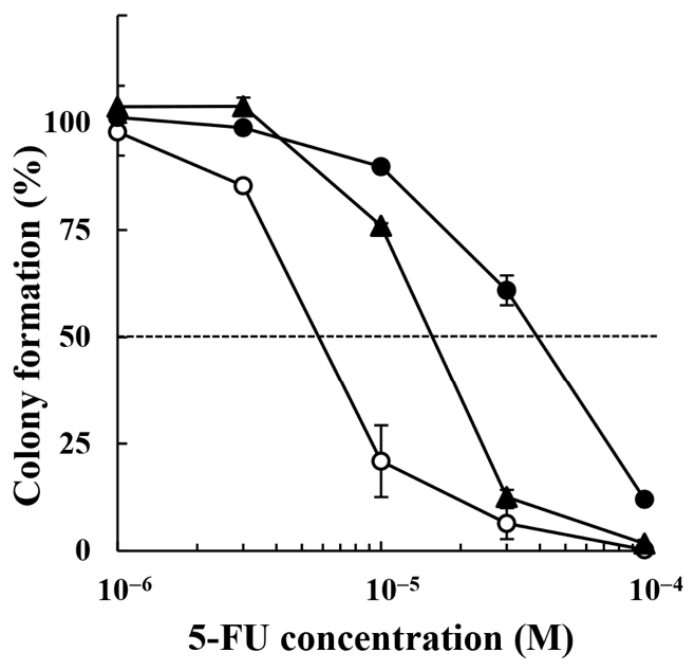

(e)

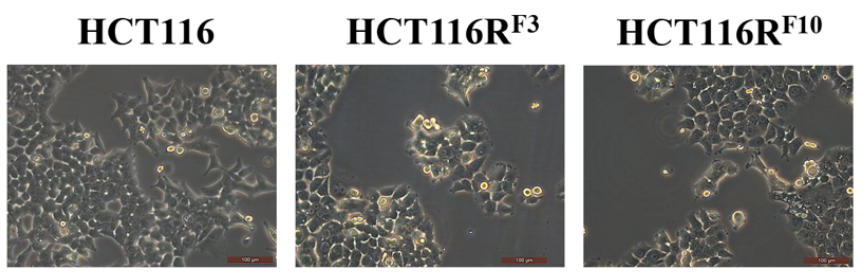

Figure 1. Establishment of $\mathrm{HCT} 116 \mathrm{R}^{\mathrm{F} 10}$, a 5-FU-resistant derivative of the human colorectal cancer cell line HCT116. (a) Scheme for the establishment of the 5-FU-resistant HCT116 cells $\left(\mathrm{HCT}_{\left.116 \mathrm{R}^{\mathrm{F} 10}\right) \text {. (b) HCT116R }} \mathrm{F}^{\mathrm{F} 10}\right.$ and parental HCT116 cells were tested for cell viability after a $72 \mathrm{~h}$ treatment with 5-FU. Results represent the averages of three independent experiments with error bars showing \pm SE from triplicates. (c) Drug sensitivities of HCT116R ${ }^{\mathrm{F} 10}$ and HCT116 using the colony formation assay. HCT116R ${ }^{\mathrm{F} 10}$ and HCT116 cells were treated with the indicated concentration of 5-FU and incubated for 10 days. (d) HCT116 cells: Colony formation (\%) represents the average of two independent experiments, each performed in duplicate, with error bars showing \pm SE of four measurement values. HCT116 $\mathrm{R}^{\mathrm{F} 3}$ and $\mathrm{R}^{\mathrm{F} 10}$ cells: Colony formation (\%) represents the average of three independent experiments, each performed in triplicate, with error bars showing \pm SE of nine measurement values. White circle, HCT116 cells; black triangle, HCT116R ${ }^{\mathrm{F} 3}$ cells; black circle, HCT116R ${ }^{\mathrm{F} 10}$ cells. (e) Morphological features were analyzed using a Leica DMi1 microscope with LAS V4.12 at $200 \times$ magnification. Scale bar $=100 \mu \mathrm{m}$.

Table 1. Sensitivity of 5-fluorouracil in the parental HCT116, HCT116R ${ }^{\mathrm{F} 3}$ and HCT116R ${ }^{\mathrm{F} 10}$ cells.

\begin{tabular}{ccccc}
\hline \multirow{2}{*}{ Cell line } & \multicolumn{2}{c}{ EC $_{\text {50 }}$ (M) } & \multicolumn{2}{c}{ RI } \\
\cline { 2 - 5 } & WST-8 Assay & CFA & WST-8 Assay & CFA \\
\hline HCT116 & $5.1 \times 10^{-6}$ & $5.5 \times 10^{-6}$ & 1 & 1 \\
HCT116R $^{\mathrm{F} 3}$ & $1.5 \times 10^{-5}$ & $1.6 \times 10^{-5}$ & 2.9 & 2.9 \\
HCT116R $^{\mathrm{F} 10}$ & $2.9 \times 10^{-5}$ & $3.8 \times 10^{-5}$ & 5.7 & 6.9 \\
\hline
\end{tabular}

Note. $\mathrm{EC}_{50}, 50 \%$ effective concentration; R, resistant; F3, fluorouracil $3 \times 10^{-6} \mathrm{M} ; \mathrm{F} 10$, fluorouracil $10 \times 10^{-6} \mathrm{M}$ RI, resistance index.

\subsection{Anticancer Drug Response of the 5-FU-Resistant HCT116 Cells}

We examined the effects of several anticancer drugs, including the 5-FU analog FUdR, SN-38, an active metabolite of irinotecan, and CDDP, on the proliferation of parental HCT116 and 5-FU-resistant HCT116R ${ }^{\text {F10 }}$ cells by WST-8 (Figure 2) and colony formation assays (Figure 3). As shown in Table 2 and Figure 2a, HCT116R ${ }^{\mathrm{F} 10}$ cells were 80.0 -fold $\left(\mathrm{EC}_{50}=1.2 \times 10^{-4} \mathrm{M}\right)$ more resistant to FUdR than parental HCT116 cells $\left(\mathrm{EC}_{50}=1.5 \times 10^{-6} \mathrm{M}\right)$. In contrast, the resistant index for SN-38 and CDDP was 2.1fold $\left(\mathrm{EC}_{50}=6.6 \times 10^{-9} \mathrm{M}\right.$ in HCT116R ${ }^{\mathrm{F} 10}$ cells; $3.1 \times 10^{-9} \mathrm{M}$ in HCT116 cells) and 1.4-fold 
$\left(\mathrm{EC}_{50}=1.4 \times 10^{-5} \mathrm{M}\right.$ in HCT116R ${ }^{\mathrm{F} 10}$ cells; $1.0 \times 10^{-5} \mathrm{M}$ in HCT116 cells $)$, respectively (Table 2, Figure $2 \mathrm{~b}, \mathrm{c})$. Similarly, for the colony-forming assay, HCT116 ${ }^{\mathrm{F} 10}$ cells were 9.7-fold $\left(\mathrm{EC}_{50}=3.3 \times 10^{-5} \mathrm{M}\right)$ more resistant to FUdR than the parental HCT116 cells $\left(\mathrm{EC}_{50}=3.4 \times 10^{-6} \mathrm{M}\right)$ (Figure 3a). In addition, the RI of SN-38 and CDDP was 0.7-fold $\left(\mathrm{EC}_{50}=3.0 \times 10^{-9} \mathrm{M}\right.$ in HCT116R $\mathrm{F}^{\mathrm{F} 10}$ cells; $4.2 \times 10^{-9} \mathrm{M}$ in HCT116 cells) and 0.9-fold $\left(\mathrm{EC}_{50}=4.5 \times 10^{-6} \mathrm{M}\right.$ in HCT116R $\mathrm{R}^{\mathrm{F} 10}$ cells; $5.2 \times 10^{-6} \mathrm{M}$ in HCT116 cells), respectively (Table 2, Figure $3 \mathrm{~b}, \mathrm{c}$ ). These results indicate that 5-FU-resistant HCT116R ${ }^{\mathrm{F} 10}$ cells exhibit cross-resistance to FUdR but collateral sensitivity to the anticancer drugs SN-38 and CDDP. This finding suggests that the HCT116R ${ }^{\mathrm{F} 10}$ cells are resistant not only to 5-FU but also to other 5-FU deoxyribose analogs such as FUdR.

Table 2. Sensitivities of several anticancer agents in the parental HCT116 and HCT116R ${ }^{\mathrm{F} 10}$ cells.

\begin{tabular}{ccccccc}
\hline & \multicolumn{3}{c}{ EC $_{\text {50 }}$ (M, WST-8) } & \multicolumn{3}{c}{ EC $_{\text {50 }}$ (M, CFA) } \\
\cline { 2 - 7 } & HCT116 & HCT116R $^{\text {F10 }}$ & RI & HCT116 & HCT116R $^{\text {F10 }}$ & RI \\
\hline FUdR & $1.5 \times 10^{-6}$ & $1.2 \times 10^{-4}$ & 80.0 & $3.4 \times 10^{-6}$ & $3.3 \times 10^{-5}$ & 9.7 \\
SN-38 & $3.1 \times 10^{-9}$ & $6.6 \times 10^{-9}$ & 2.1 & $4.2 \times 10^{-9}$ & $3.0 \times 10^{-9}$ & 0.7 \\
CDDP & $1.0 \times 10^{-5}$ & $1.4 \times 10^{-5}$ & 1.4 & $5.2 \times 10^{-6}$ & $4.5 \times 10^{-6}$ & 0.9 \\
\hline
\end{tabular}

Note: $\mathrm{EC}_{50}, 50 \%$ effective concentration; $\mathrm{R}^{\mathrm{F} 10}$, resistant to fluorouracil $10 \times 10^{-6} \mathrm{M}$; RI, resistance index.

(a)

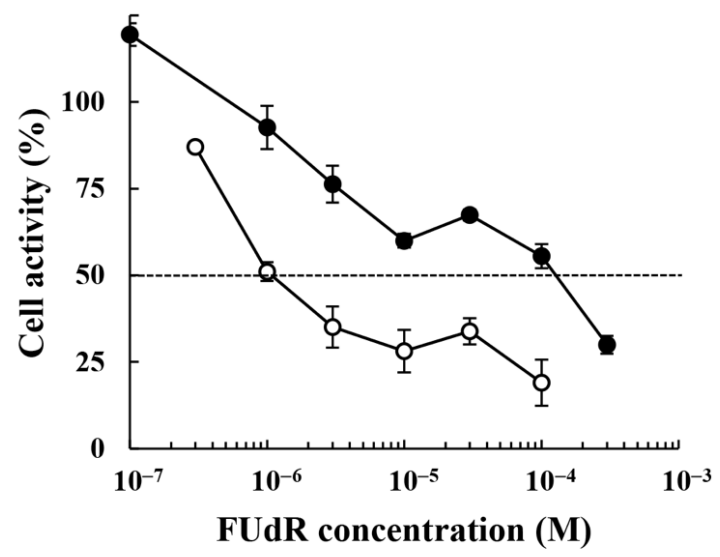

(c)

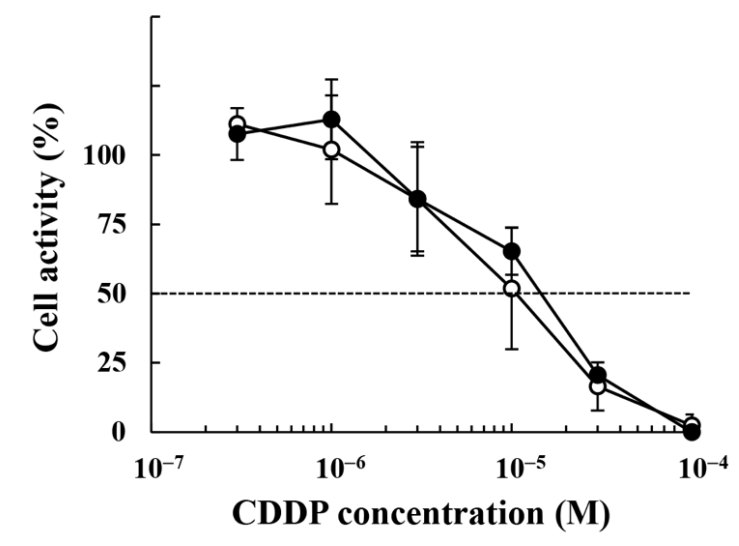

(b)

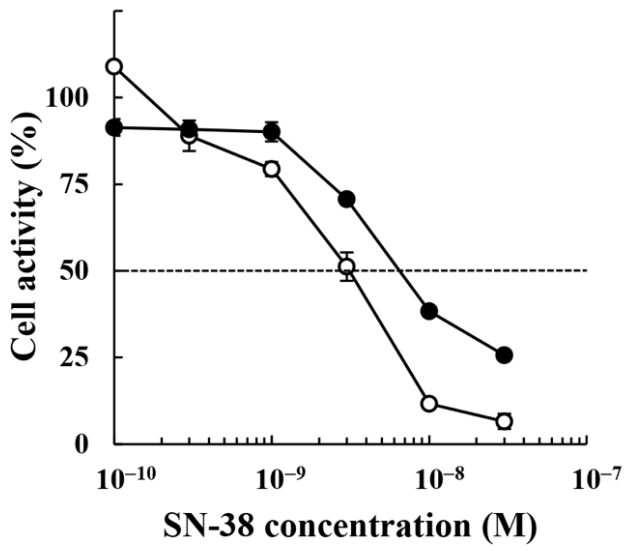

Figure 2. Sensitivity of 5-FU-resistant $H C T 116 R^{\mathrm{F} 10}$ and parental HCT116 cells to FUdR, SN-38, and CDDP. The cell proliferation WST-8 assay of HCT116R ${ }^{\mathrm{F} 10}$ and parental HCT116 cells after a $72 \mathrm{~h}$ treatment with (a) FUdR, (b) SN-38, and (c) CDDP. Results represent the averages of two independent experiments, with error bars showing \pm SE of triplicates. White circle, HCT116 cells; black circle, HCT116R ${ }^{\mathrm{F} 10}$ cells. 
(a)

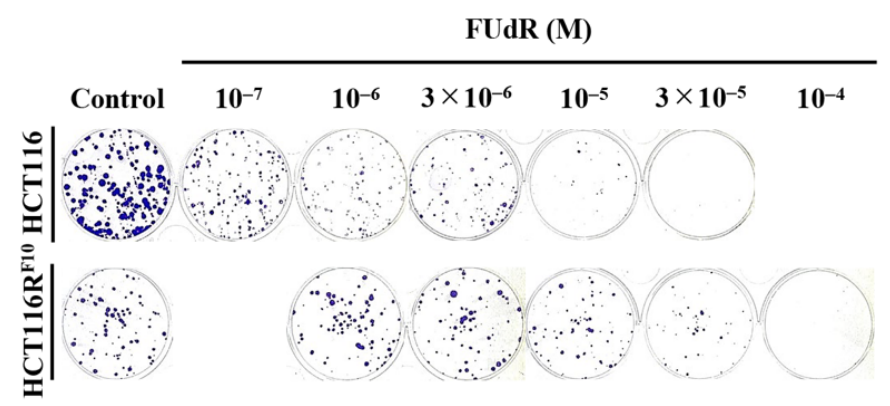

(c)

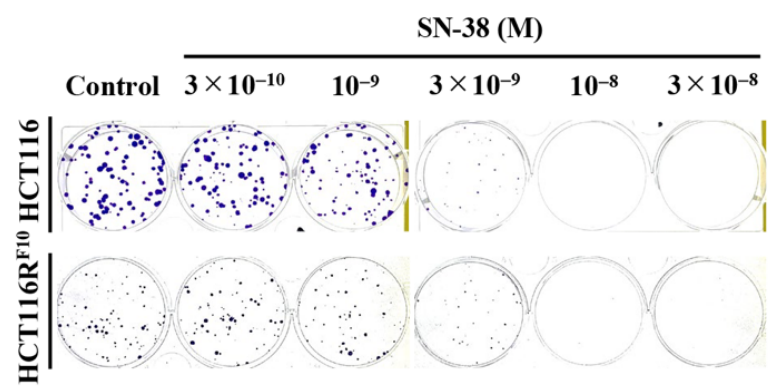

(e)

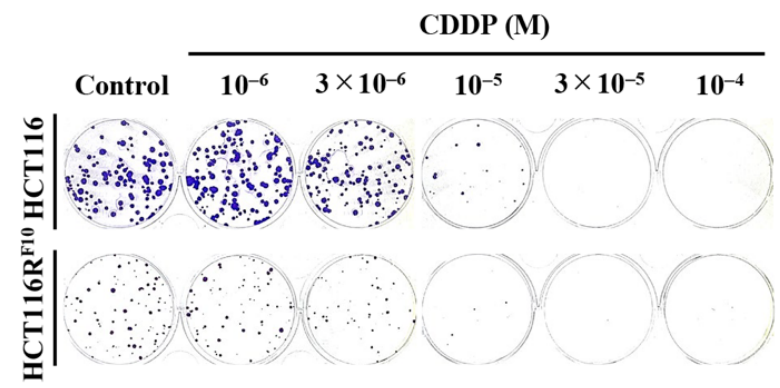

(b)

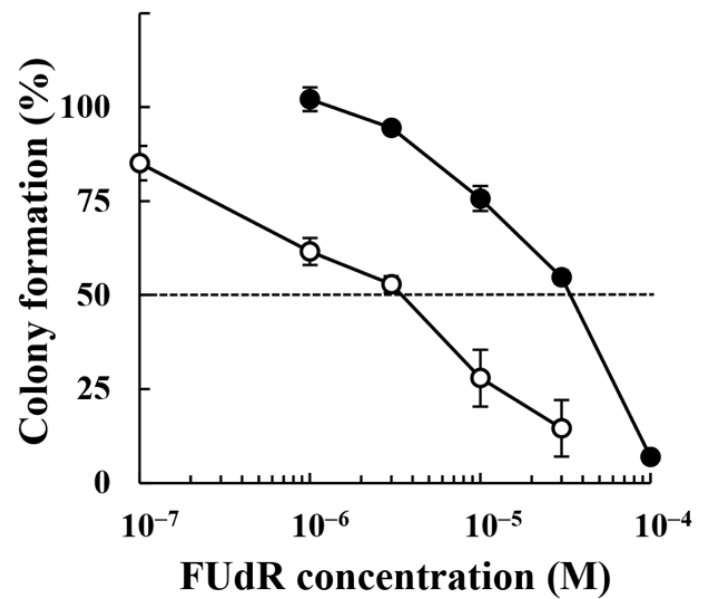

(d)

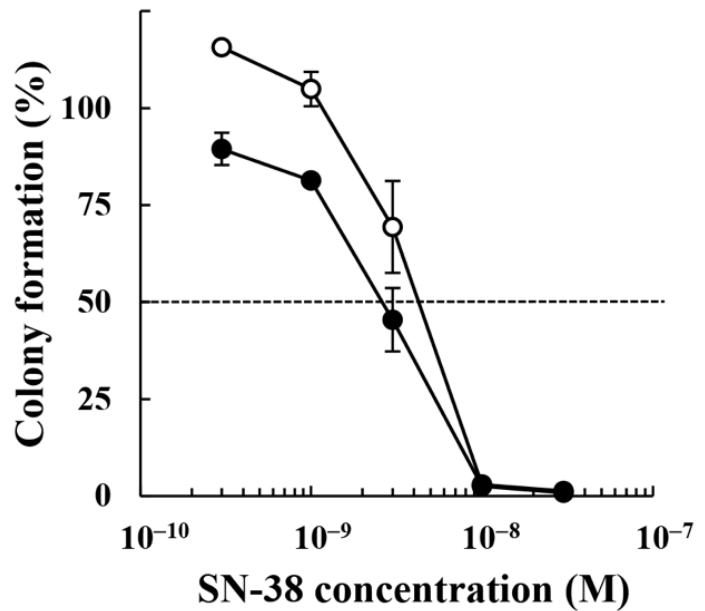

(f)

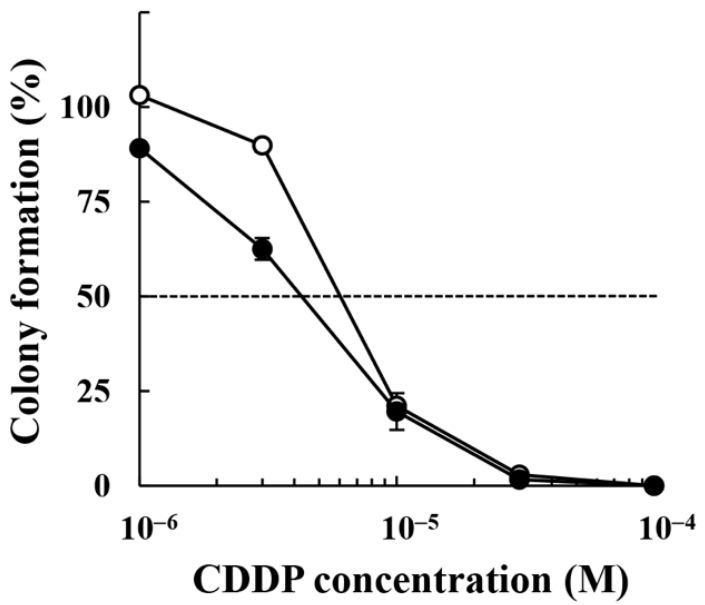

Figure 3. Sensitivity of 5-FU-resistant HCT116R ${ }^{\mathrm{F} 10}$ and parental HCT116 cells to FUdR, SN-38, and CDDP. Colony formation by HCT116R ${ }^{\mathrm{F} 10}$ and parental HCT116 cells after 10 days of treatment with $(\mathbf{a}, \mathbf{b}) \mathrm{FUdR},(\mathbf{c}, \mathbf{d})$ SN-38, and $(\mathbf{e}, \mathbf{f})$ CDDP. Colony formation (\%) represents the averages of two independent experiments each performed in duplicate (b) or triplicate $(\mathbf{d}, \mathbf{f})$, with error bars showing $\pm \mathrm{SE}$ of four $(\mathbf{b})$ or six $(\mathbf{d}, \mathbf{f})$ measurement values. White circle, HCT116 cells; black circle, HCT116R ${ }^{\mathrm{F} 10}$ cells. 


\subsection{Biological Features of the 5-FU-Resistant HCT116 Cells}

We analyzed the tumor sphere formation ability of HCT116R ${ }^{\mathrm{F} 10}$ cells and parental HCT116 cells in three-dimensional cell culture experiments (Figure 4). HCT116R ${ }^{\text {F10 }}$ cells exhibited a lower ability to form tumor spheres compared with parental HCT116 cells under untreated conditions (Figure $4 \mathrm{a}$ left panel and b). Interestingly, HCT116R ${ }^{\mathrm{F} 10}$ cells maintained a tumor sphere formation ability compared with parent HCT116 cells during 5-FU treatment conditions (Figure $4 \mathrm{a}, \mathrm{c}$ ). We next examined the sensitivity of parental HCT116 and HCT116R $\mathrm{R}^{\mathrm{F} 10}$ tumor sphere cells to 5-FU. As shown in Figure 4d, HCT116R $\mathrm{R}^{\mathrm{F} 10}$ cells were 18.7-fold $\left(\mathrm{EC}_{50}=2.8 \times 10^{-5} \mathrm{M}\right)$ more resistant to 5-FU than parental HCT116 cells $\left(\mathrm{EC}_{50}=1.5 \times 10^{-6} \mathrm{M}\right)$. These data indicate that 5-FU-resistant HCT116R ${ }^{\mathrm{F} 10}$ cells are less prone to tumorigenesis than sensitive, parental HCT116 cells, but formed tumor spheres that retained a higher 5-FU resistance.

(a)

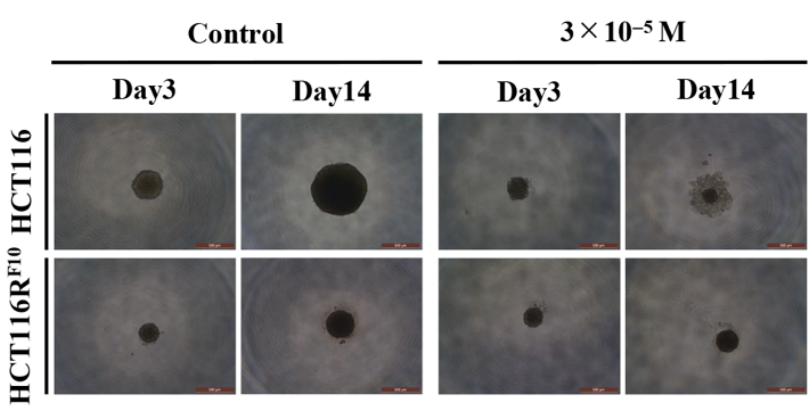

(b)

Control

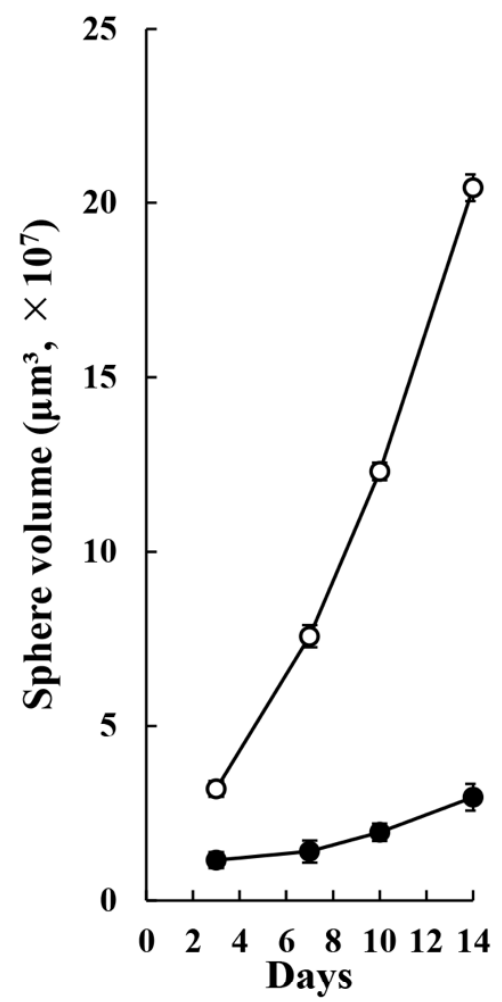

(c)

\section{$3 \times 10^{-5} \mathrm{M}$}

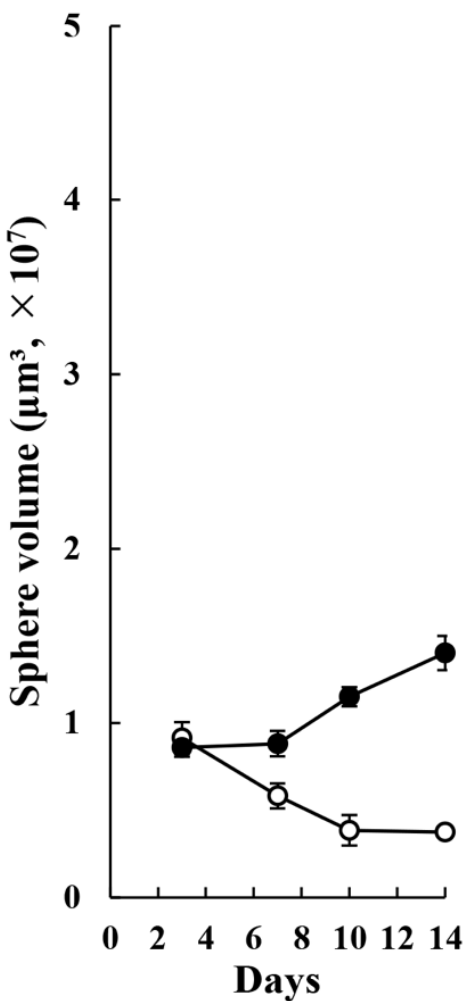

Figure 4. Cont. 
(d)

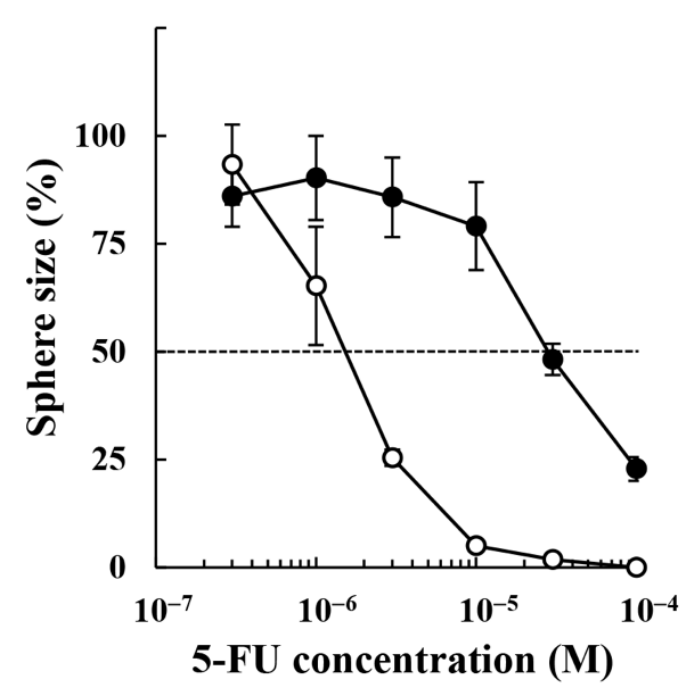

Figure 4. Tumor sphere formation of 5-FU-resistant HCT116R $\mathrm{R}^{\mathrm{F} 10}$ and parental HCT116 cells. (a) Tumor sphere formation was analyzed using a Leica DMi1 microscope with $50 \times$ magnification. Scale bar $=500 \mu \mathrm{m}$. HCT116R $\mathrm{R}^{\mathrm{F} 10}$ and parental HCT116 cells were treated with or without $3 \times 10^{-5} \mathrm{M}$ 5-FU for 3 or 14 days. Control, no 5-FU, solvent (DMSO) alone. To assess the ability of HCT116R F10 and parental HCT116 cells to form tumor spheres, the cells were treated with solvent alone (b) or $3 \times 10^{-5}$ M 5-FU (c) for 14 days. Tumor sphere size was calculated as described in the Materials and Methods. White circle, HCT116 cells; black circle, HCT116R ${ }^{\text {F10 }}$ cells. (d) Drug sensitivity of 5-FU in HCT116 and HCT116R ${ }^{\mathrm{F} 10}$ tumor spheres. Tumor sphere formation by HCT116R ${ }^{\mathrm{F} 10}$ and parental HCT116 cells after a 14-day treatment with 5-FU at the indicated concentrations. Results are the averages for groups of three tumor spheres each with error bars showing SE. White circle, HCT116 cells; black circle, HCT116R ${ }^{\mathrm{F} 10}$ cells.

\subsection{Exome Sequencing Analysis of HCT116 Parent Cells and 5-FU-Resistant HCT116R ${ }^{F 10}$ Cells}

We analyzed variants of 5-FU metabolic pathway-related enzyme genes, including TYMS, which encodes for TS, and DPYD, which encodes for DPD in HCT116 and HCT116R F10 $^{2}$ cells. TS is a major intracellular target of 5-FU, whereas DPD catalyzes the rate-limiting step in the catabolism of 5-FU $[2,3,11]$. The pathways involved in the metabolism of 5-FU and its analog FUdR are shown in Figure 5. The genetic alteration status of nearly all of the 5-FU metabolic pathway-related genes was of similar status in both cells. Importantly, the variants of TYMS and DPYD in HCT116 and HCT116R ${ }^{\mathrm{F} 10}$ cells contained heterozygous mutations or intron variants. We identified two TYMS intron variants, 454+197_454+202delTTTTTT and 454+199_454+202delTTTT, in HCT116R ${ }^{\mathrm{F} 10}$ cells. In contrast, only one TYMS intron variant, 454+200_454+202delTTT, was present in sensitive parental HCT116 cells. Similarly, the three DPYD variants, 2999A >T, 2623-59T>G, and $2442+78 \mathrm{delA}$, were present in the HCT116R ${ }^{\mathrm{F} 10}$ cells. In addition, three DPYD variants, 2442+77_2442+delAA, 40-461delT, and -113T>C, were present in HCT116 cells. Herein, we show that one of the DPYD heterozygous variants, 2999A $>\mathrm{T}$, is a missense mutation (Asp1000Val) in DPD of 5-FU-resistant HCT116R ${ }^{\mathrm{F} 10}$ cells. 


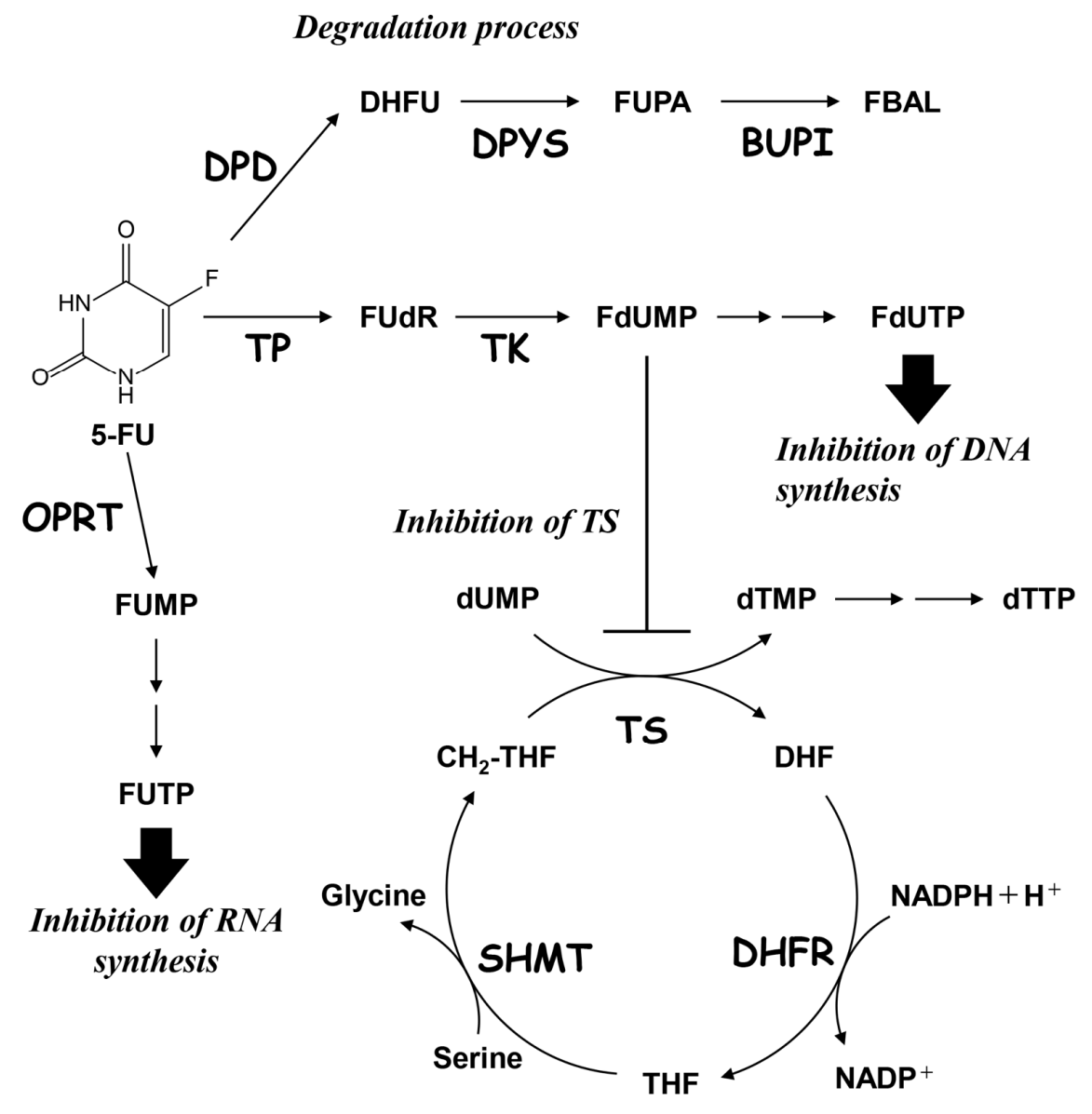

Figure 5. Metabolic pathways associated with 5-FU. 5-FU, 5-fluorouracil; DHFU, dihydrofluorouracil; FUPA, fluoroureidopropionate; FBAL, fluoroalanine; FUdR, fluorodeoxyuridine; FdUMP, fluorodeoxyuridine monophosphate; FdUTP, fluorodeoxyuridine triphosphate; FUMP, fluorouridine monophosphate; FUTP, fluorouridine triphosphate; dUMP, deoxyuridine monophosphate; dTMP, deoxythymidine monophosphate; dTTP, deoxythymidine triphosphate; $\mathrm{CH}_{2}-\mathrm{THF}, 5,10$-methylenetetrahydrofolate; DHF, dihydrofolate; THF; tetrahydrofolate; TS, thymidylate synthase; DPD, dihydropyrimidine dehydrogenase; DPYS, dihydro pyrimidase; DHFR, dihydrofolate reductase; BUPI, $\beta$-ureido propionase; TP, thymidine phosphorylase; TK, thymidine kinase; SHMT, serine hydroxymethyltransferase; and OPRT, orotate phosphoribosyltransferase 1.

\subsection{Regulation of TS and DPD in HCT116 Parent Cell and 5-FU-Resistant HCT116R F10 Cells}

To elucidate the association of TS and DPD expression with 5-FU resistance, we analyzed TS and DPD expression levels in parental HCT116 and 5-FU-resistant HCT116R R10 cells by Western blot analysis (Figure 6a). Interestingly, as shown in Figure 6a (top panel) and $6 \mathrm{~b}$, free-TS protein levels were almost identical in HCT116 ${ }^{\mathrm{F} 10}$ and HCT116 cells.

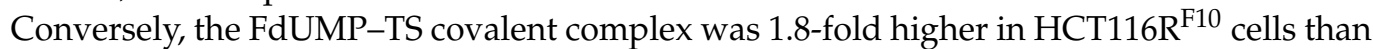
in HCT116 cells (Figure 6a top panel and 6c). Importantly, it should be noted that total TS, the free form, the FdUMP-covalent form, and total TS was overexpressed in HCT116R $\mathrm{R}^{\mathrm{F10}}$ cells rather than in HCT116 cells (Figure 6a top panel and Figure 6d). The upper band of TS, indicated FdUMP-covalent form, which represents TS in ternary complexes and is correlated with the intracellular concentration of FdUMP [12-14]. In addition, DPD protein levels were slightly decreased in HCT116 ${ }^{\mathrm{F} 10}$ cells than in parental HCT116 cells (Figure 6a second panel and Figure 6e). GAPDH and beta-actin were used as an internal controls (Figure 6a third and bottom panels). In parental HCT116 cells and HCT116R ${ }^{\mathrm{F} 10}$ cells, both internal control proteins, GAPDH and beta-actin, had similar levels. After treatment with $1 \times 10^{-4} \mathrm{M} 5$-FU for $24 \mathrm{~h}$, the protein levels of free TS, FdUMP-TS covalent complex, and total TS were individually about 1.5-fold higher in HCT116R ${ }^{\mathrm{F} 10}$ cells than in parental HCT116 cells (Figure 7a-d). Intriguingly, these data indicated that the proportion of active 
free TS in the intracellular total TS was highly regulated in the 5-FU resistant HCT116R $\mathrm{R}^{\mathrm{F} 10}$ cells. These findings suggested that the regulation of TS status, which includes the balance of active free TS or the inactive FdUMP-TS covalent complex, may confer resistance to 5 -FU.

(a)

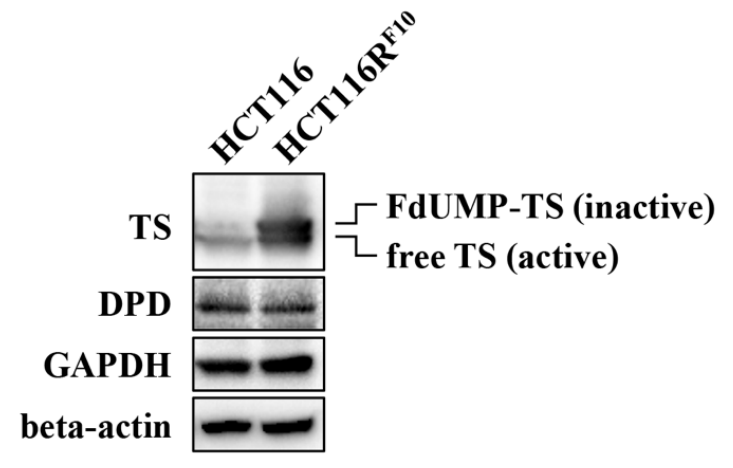

(c)

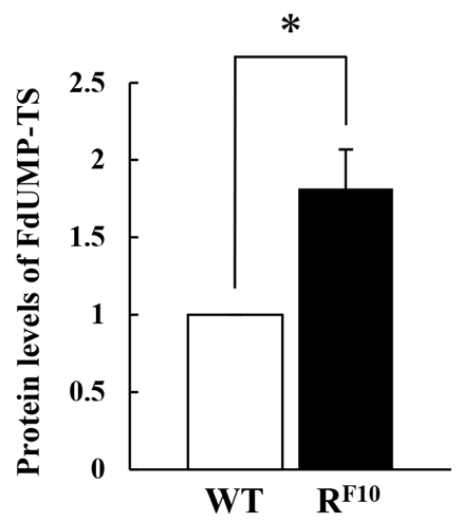

(e)

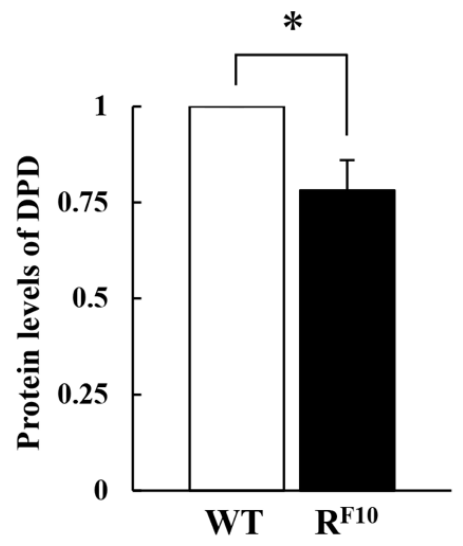

(b)

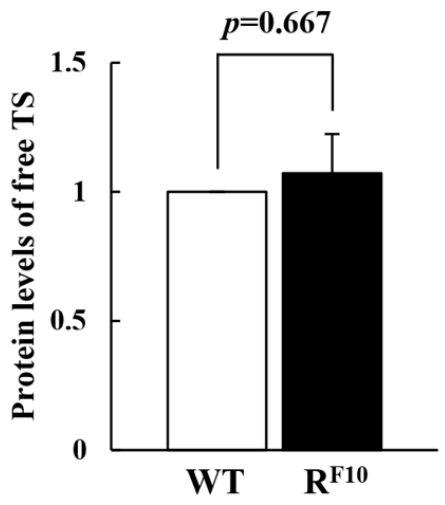

(d)

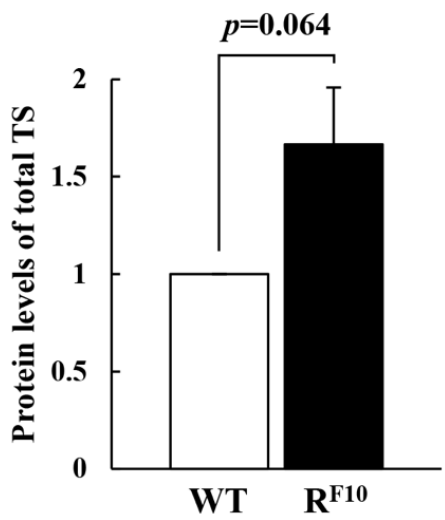

Figure 6. Protein levels of TS and DPD in 5-FU-resistant HCT116R ${ }^{\mathrm{F} 10}$ and parental HCT116 cells. (a) Whole-cell lysates were prepared from parental HCT116 and HCT116R ${ }^{\mathrm{F} 10}$ cells. Protein levels of TS, DPD, GAPDH, and beta-actin were measured by Western blot analysis. The expression levels of GAPDH and beta-actin were used as an internal control. Data are representative of at least three independent experiments. Protein levels of (b) free TS, (c) FdUMP-TS, (d) total TS, and (e) DPD in parental HCT116 and HCT116R ${ }^{\text {F10 }}$ cells. Levels of TS and DPD protein in HCT116R ${ }^{\mathrm{F} 10}$ cells are represented by the ratio of TS or DPD density to GAPDH density relative to the value for parental HCT116 cells. Results represent the averages of three independent experiments with error bars showing \pm SE of triplicates. ${ }^{*} p<0.05$. 
(a)

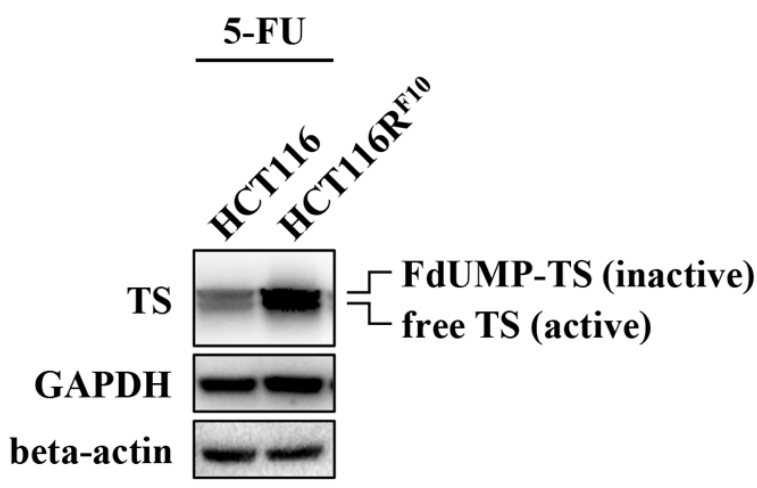

(c)

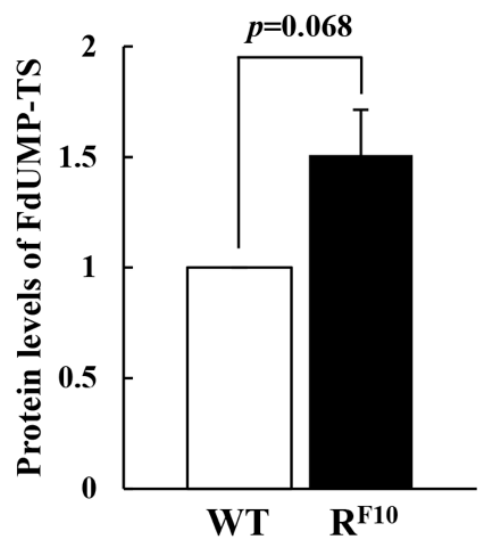

(b)

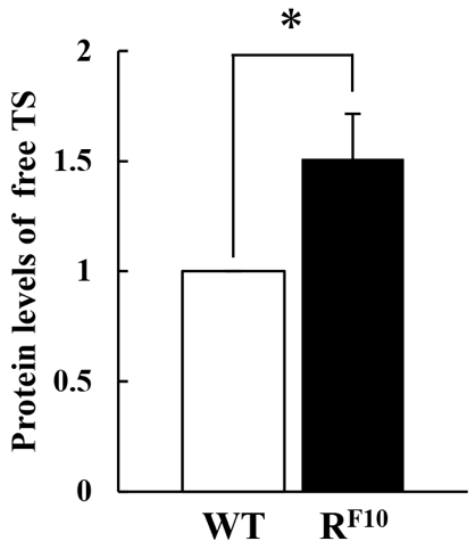

(d)

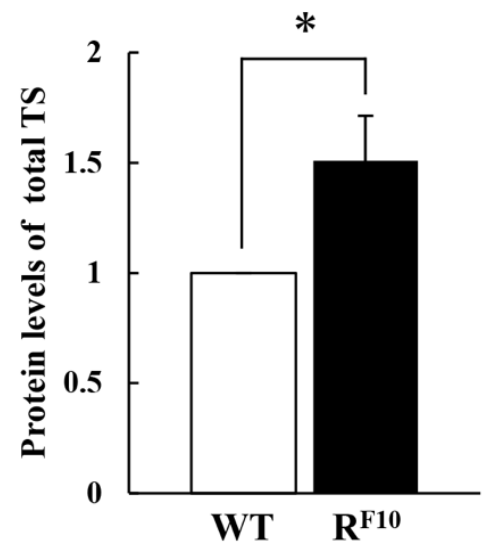

Figure 7. Protein levels of TS in 5-FU-resistant HCT116R ${ }^{\mathrm{F} 10}$ and parental HCT116 cells after treatment with 5-FU. (a) Wholecell lysates were prepared from parental HCT116 and HCT116R ${ }^{\mathrm{F} 10}$ cells after $24 \mathrm{~h}$ treatment with $1 \times 10^{-4} \mathrm{M} 5$-FU. Protein levels of TS, GAPDH, and beta-actin were measured by Western blot analysis. Data are representative of at least three independent experiments. Protein levels of (b) free TS, (c) FdUMP-TS, and (d) total TS in parental HCT116 and HCT116R ${ }^{\mathrm{F} 10}$ cells. Levels of TS protein in HCT116R ${ }^{\mathrm{F} 10}$ cells are represented by the ratio of TS density to GAPDH density relative to the value for parental HCT116 cells. Results represent the averages of three independent experiments with error bars showing \pm SE of triplicates. * $p<0.05$.

\section{Discussion}

5 -FU and its derivatives are widely used in anticancer chemotherapy [2,3]. Studies to date have shown that cancer cells develop resistance to 5-FU through complex mechanisms [2,3]. Of note, the TS enzyme and other enzymes involved in 5-FU anabolism or catabolism are often altered in expression or function to promote 5-FU resistance [2,3]. In addition, altered cell death and autophagy, expression/functional changes in drug transporters, epigenetic changes, and non-coding RNA (i.e., microRNA and long non-coding RNA) dysfunction represent putative 5-FU-resistant mechanisms [2,3]. It has been widely believed that TS is the main molecular mechanism that influences 5-FU sensitivity and targeting TS is a major strategy for reversing 5-FU resistance. Importantly, there are currently no specific therapies to overcome 5-FU resistance.

We established a 5-FU-resistant cell line, $\mathrm{HCT} 116 \mathrm{R}^{\mathrm{F} 10}$, and analyzed its characteristics. Importantly, $\mathrm{HCT} 116 \mathrm{R}^{\mathrm{F} 10}$ cells were cross-resistant to the 5-FU analog, FUdR (Figures 2 and 3). In contrast, HCT116R ${ }^{\mathrm{F} 10}$ cells did not exhibit cross-resistance to the anticancer drugs, SN-38 and CDDP (Figures 2 and 3). Similarly, Boyer et al. also reported that 5-FU- 
resistant HCT116 cells were not cross-resistant to oxaliplatin or irinotecan [15]. In addition, the sensitivities to 5-FU and FUdR were similar to the levels observed individually in parental HCT116 cells. Of note, previous reports indicated that FUdR is more potent than 5-FU and that the inhibition of cell proliferation was approximately 10- to 100-fold higher than that of 5-FU in multiple cancer cell lines [16-18]. These findings suggest that the common target or mechanism of action of 5-FU and FUdR is the key to 5-FU resistance in this resistant cell model. Furthermore, our results revealed that HCT116R ${ }^{\mathrm{F} 10}$ cells are resistant to 5-FU and its derivatives, but are not multidrug resistant.

To elucidate the underlying cause of 5-FU resistance, we investigated 5-FU metabolismrelated genes, including TYMS and DPYD, in HCT116 $\mathrm{R}^{\mathrm{F} 10}$ and parent HCT116 cells by using whole-exome sequencing. The results revealed that the genetic alteration of almost all of the 5-FU metabolic pathway-related genes was similar in status, intron variants, and heterozygous mutation in both cells (Table 3). Interestingly, we found that the one functional DPD mutation, Asp1000Val, is present in HCT116R ${ }^{\mathrm{F} 10}$ cells. However, the effects of DPYD missense mutation on 5-FU resistance are not well understood.

Next, to evaluate TS and DPD in HCT116 ${ }^{\mathrm{F} 10}$ and parent HCT116 cells, we analyzed the expression of these genes by Western blot analysis (Figure 6). 5-FU and FUdR are converted to FdUMP, and it has been shown to form a covalent complex with TS in the presence of $\mathrm{CH}_{2}$-THF [2,3,5]. Our results indicated that the free-TS protein (active form) levels were similar in HCT116R ${ }^{\mathrm{F} 10}$ and HCT116 cells. Interestingly, the FdUMP-TS covalent complex (inactive form) was higher in HCT116R ${ }^{\mathrm{F} 10}$ cells than in HCT116 cells. Notably, this result indicates that TS is not overexpressed, but rather there are two types of TS in HCT116R ${ }^{\mathrm{F} 10}$ cells: free TS and FdUMP-coupled TS. We observed that 5-FU-resistant HCT116R ${ }^{\mathrm{F} 10}$ cells exhibit upregulated TYMS expression and use a fraction of TS to trap FdUMP, resulting in resistance to 5-FU and its analogs. In addition, our data suggest that the regulation of the TS complex, which refers to the balance of the active free-TS form and the inactive FdUMP-TS covalent complex, may confer to 5-FU resistance.

Numerous studies have shown that TYMS gene amplification, leading to mRNA and enzyme overproduction, is a major mechanism of resistance to fluoropyrimidines 5-FU and FUdR and their derivatives [19]. Also, free TS binds to its own mRNA, resulting in translational repression, that is, translational autoregulation [12,20-23]. Indeed, TS ligands, including 5-FU, disrupt the interaction of the TS enzyme with TS mRNA, leading to translational derepression and enzyme upregulation [12,22,23]. Additionally, to translational derepression, enzyme stabilization has been indicated as the primary mechanism of TS induction by fluoropyrimidines in human colon and ovarian cancer cell lines [24-26]. Furthermore, it is proposed that fluoropyrimidine-mediated increases in TS levels occur through an effect on enzyme stability with no effect on its mRNA [25,27]. It is also suggested that TS stabilization could be the result of conformational changes that may occur upon the formation of a ternary complex, reducing the susceptibility of the TS enzyme to proteolysis [28]. These findings indicated that understanding translational derepression and enzyme stabilization as the process of TS induction has significance for elucidating the mechanism of resistance acquisition. Further investigation is needed on the functions of the FdUMP-TS covalent complex and free TS in both translational regulation and enzyme stabilization for fluoropyrimidine resistance mechanisms using 5-FU-resistance and 5-FU-sensitive parental HCT116 cell lines. Collectively, our findings provide a better understanding of the anticancer drugs, 5-FU and its fluoropyrimidine derivatives, with respect to resistance mechanisms and anticancer treatment strategies. 
Table 3. Mutations of 5-FU metabolic enzyme genes in the parental HCT116 and HCT116R ${ }^{\mathrm{F} 10}$ cells.

\begin{tabular}{|c|c|c|}
\hline Gene Symbol & HCT116 & HCT116R $^{\text {F10 }}$ \\
\hline DPYD & 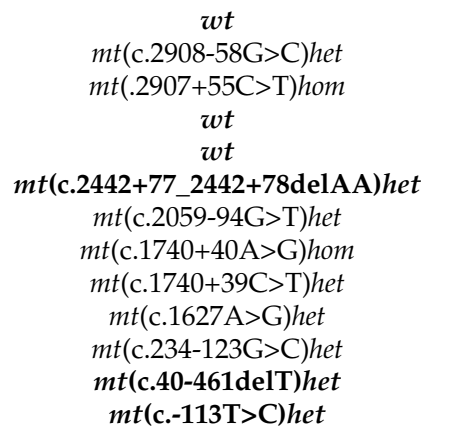 & 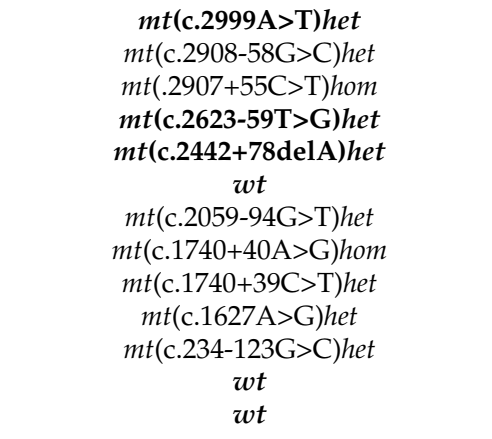 \\
\hline DPYS & $\begin{array}{c}\text { mt }(\text { c. } 1444-145 \mathrm{C}>\mathrm{T}) \text { hom } \\
\text { mt }(\text { c.951-113T }>\mathrm{C}) \text { hom } \\
\text { mt }(\mathrm{c} .424-62 \mathrm{G}>\mathrm{T}) \text { hom } \\
\text { mt }(\mathrm{c} .265-58 \mathrm{~T}>\mathrm{C}) \text { hom } \\
\text { mt }(\mathrm{c} .216 \mathrm{C}>\mathrm{T}) \text { hom } \\
\text { mt (c. }-1 \mathrm{~T}>\mathrm{C}) \text { hom }\end{array}$ & $\begin{array}{c}\text { mt }(\text { c. } 1444-145 \mathrm{C}>\mathrm{T}) \text { hom } \\
\text { mt (c.951-113T }>\mathrm{C}) \text { hom } \\
\text { mt (c. } 424-62 \mathrm{G}>\mathrm{T}) \text { hom } \\
\text { mt }(\mathrm{c} .265-58 \mathrm{~T}>\mathrm{C}) \text { hom } \\
\text { mt }(\mathrm{c} .216 \mathrm{C}>\mathrm{T}) \text { hom } \\
\text { mt (c. }-1 \mathrm{~T}>\mathrm{C}) \text { hom }\end{array}$ \\
\hline$B U P I$ & n.d. & n.d. \\
\hline$T P$ & n.d. & n.d. \\
\hline TK1 & $\begin{array}{c}m t(\mathrm{c} .393+168 \mathrm{C}>\mathrm{T}) \text { het } \\
m t(\mathbf{c} .393+1 \mathrm{G}>\mathrm{A}) \text { het } \\
m t(\mathrm{c} .225 \mathrm{~A}>\mathrm{G}) \text { het } \\
m t\left(\mathrm{c} .98+97 \_98+101 \text { delCCCCT }\right) \text { het } \\
m t(\mathrm{c} .33 \mathrm{~T}>\mathrm{C}) \text { het }\end{array}$ & $\begin{array}{c}w t \\
w t \\
m t(\mathrm{c} .225 \mathrm{~A}>\mathrm{G}) h e t \\
m t\left(\mathrm{c} .98+97 \_98+101 \text { delCCCCT }\right) h e t \\
m t(\mathrm{c} .33 \mathrm{~T}>\mathrm{C}) \text { het }\end{array}$ \\
\hline$T K 2$ & $\begin{array}{c}m t(\mathrm{c} .619-53 \mathrm{~A}>\mathrm{G}) h e t \\
m t(\mathrm{c} .619-63 \mathrm{C}>\mathrm{G}) h e t \\
m t(\mathrm{c} .156+836 \mathrm{G}>\mathrm{A}) h e t \\
m t(\mathrm{c} .156+742 \mathrm{G}>\mathrm{A}) h e t \\
m t(\mathrm{c} .125-116 \mathrm{G}>\mathrm{A}) h e t \\
m t(\mathrm{c} .30 \mathrm{C}>\mathrm{G}) h e t \\
m t(\mathrm{c} .38 \mathrm{~A}>\mathrm{G}) h e t\end{array}$ & $\begin{array}{c}m t(\text { c.619-53A }>\mathrm{G}) h e t \\
m t(\mathrm{c} .619-63 \mathrm{C}>\mathrm{G}) h e t \\
m t(\mathrm{c} .156+836 \mathrm{G}>\mathrm{A}) h e t \\
m t(\mathrm{c} .156+742 \mathrm{G}>\mathrm{A}) h e t \\
m t(\mathrm{c} .125-116 \mathrm{G}>\mathrm{A}) h e t \\
m t(\mathrm{c} .30 \mathrm{C}>\mathrm{G}) h e t \\
m t(\mathrm{c}-38 \mathrm{~A}>\mathrm{G}) h e t\end{array}$ \\
\hline TYMS & 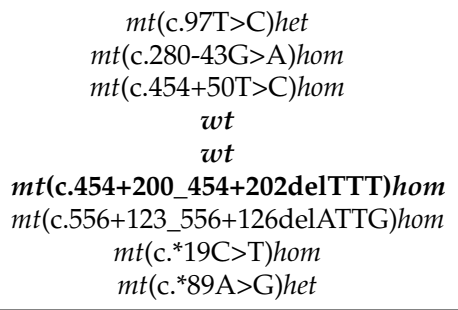 & 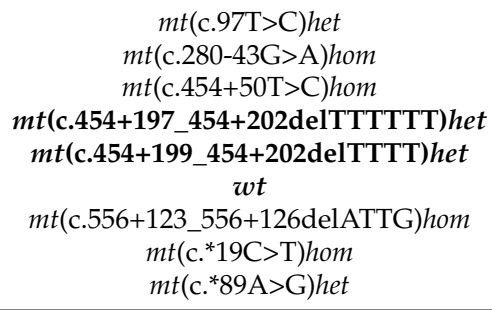 \\
\hline DHFR1 & $\begin{array}{c}w t \\
w t \\
m t(\text { c. }-204 \mathrm{~T}>\mathrm{C}) h e t\end{array}$ & $\begin{array}{c}m t(c .137-25 T>G) h e t \\
m t(c .137-43 T>C) h e t \\
m t(c .-204 T>C) h e t\end{array}$ \\
\hline DHFR2 & $m t($ c.247C >G)hom & $m t($ c.247C >G)hom \\
\hline SHMT1 & $\begin{array}{c}m t\left(\mathrm{c} .{ }^{*} 66 \mathrm{C}>\mathrm{T}\right) h e t \\
m t(\mathrm{c} .47 \mathrm{C}>\mathrm{G}) h e t \\
m t(\mathrm{c} .1420 \mathrm{C}>\mathrm{T}) h e t \\
m t(\mathrm{c} .1171+59 \mathrm{~A}>\mathrm{G}) h e t \\
m t(\mathrm{c} .1054+141 \mathrm{C}>\mathrm{T}) h e t \\
m t(\mathrm{c} .815-23 \mathrm{C}>\mathrm{T}) \text { het } \\
m t(\mathrm{c} .601+174 \mathrm{C}>\mathrm{T}) h e t \\
m t(\mathrm{c} .601+173 \mathrm{G}>\mathrm{A}) h e t \\
m t(\mathrm{c} .243-256 \mathrm{~A}>\mathrm{G}) h e t \\
m t(\mathrm{c} .19-101 \mathrm{~T}>\mathrm{C}) h o m\end{array}$ & $\begin{array}{c}m t\left(\text { c. }{ }^{*} 66 \mathrm{C}>\mathrm{T}\right) h e t \\
m t(\mathrm{c} .47 \mathrm{C}>\mathrm{G}) h e t \\
m t(\mathrm{c} .1420 \mathrm{C}>\mathrm{T}) h e t \\
m t(\mathrm{c} .1171+59 \mathrm{~A}>\mathrm{G}) h e t \\
m t(\mathrm{c} .1054+141 \mathrm{C}>\mathrm{T}) h e t \\
m t(\mathrm{c} .815-23 \mathrm{C}>\mathrm{T}) \text { het } \\
m t(\mathrm{c} .601+174 \mathrm{C}>\mathrm{T}) \text { het } \\
m t(\mathrm{c} .601+173 \mathrm{G}>\mathrm{A}) h e t \\
m t(\mathrm{c} .243-256 \mathrm{~A}>\mathrm{G}) h e t \\
m t(\mathrm{c} .19-101 \mathrm{~T}>\mathrm{C}) h o m\end{array}$ \\
\hline SHMT2 & $\begin{array}{c}m t(\mathrm{c} .595-6 \mathrm{G}>\mathrm{A}) h e t \\
m t(\mathrm{c} .717+14 \mathrm{dupG}) h e t \\
m t(\mathrm{c} .1279+30 \mathrm{G}>\mathrm{A}) \text { het }\end{array}$ & $\begin{array}{c}m t(\text { c.595-6G }>\mathrm{A}) h e t \\
m t(\mathrm{c} .717+14 \mathrm{dupG}) h e t \\
m t(\mathrm{c} .1279+30 \mathrm{G}>\mathrm{A}) \text { het }\end{array}$ \\
\hline
\end{tabular}

Note. $w t$, wild-type; $m t$, mutation-type; n.d., not detected; hom, homozygous; het, heterozygous. 


\section{Materials and Methods}

\subsection{Reagents}

The anticancer drugs 5-FU, FUdR, CDDP, and SN-38 were obtained from FUJIFILM Wako Pure Chemical Corporation (Osaka, Japan). 5-FU, CDDP, and SN-38 were stored as $100 \mathrm{mM}$ stocks in dimethyl sulfoxide (DMSO, Sigma-Aldrich; Merck KGaA, Darmstadt, Germany) at $-20{ }^{\circ} \mathrm{C}$. FUdR was stored as a $20 \mathrm{mM}$ stock solution in ultrapure water at $-20{ }^{\circ} \mathrm{C}$.

\subsection{Cell Culture}

The human colon cancer cell line HCT116 was obtained from the American Type Culture Collection. Parental and 5-FU-resistant HCT116 cell lines were cultured in DMEM medium containing $10 \%$ heat-inactivated fetal bovine serum, 100 units $/ \mathrm{mL}$ penicillin, and $100 \mu \mathrm{g} / \mathrm{mL}$ streptomycin in a $37^{\circ} \mathrm{C}$ incubator under an atmosphere containing $5 \%$ $\mathrm{CO}_{2}$ and $100 \%$ relative humidity.

\subsection{Generation of the 5-FU-Resistant HCT116 Cell Line}

5-FU-resistant HCT116 cells were obtained by continuous exposure of cells to $3 \mu \mathrm{M}$ 5-FU for approximately 12 weeks and following at $10 \mu \mathrm{M}$ for an approximate 14-week period. A derivative of HCT116 was isolated and named HCT116R ${ }^{\mathrm{F} 3}$ or HCT116R ${ }^{\mathrm{F} 10}$. The HCT116R ${ }^{\mathrm{F} 10}$ cells were maintained in culture in the presence of $10 \mu \mathrm{M} 5$-FU.

\subsection{Cell Viability by WST-8 Assay}

Cell viability assays were performed as previously described [29]. Cell viability was determined using the WST-8 (Cell Counting Kit-8) cell proliferation assay (Dojindo, Tokyo, Japan). Briefly, cells were seeded into 96-well plates (1000 cells per well) in triplicate and then treated with various concentrations of anticancer drugs or DMSO and water (as a negative control). Following incubation for $72 \mathrm{~h}$, WST- 8 reagent was added to each well and the plate was placed in a $5 \% \mathrm{CO}_{2}$ incubator at $37^{\circ} \mathrm{C}$ for an additional $1 \mathrm{~h}$. Optical density was measured at $450 \mathrm{~nm}$ on a Tecan microplate reader (Mannedorf, Switzerland). The EC 50 value was defined as the concentration of drug producing $50 \%$ inhibition of cell proliferation. The resistance index $(\mathrm{RI})$ was defined as the ratio of $\mathrm{EC}_{50}$ values between the resistant and parental cell lines. Experiments were repeated at least three times.

\subsection{Colony Formation Assay}

Colony formation assay was performed as previously described [29-32]. HCT116 and HCT116R ${ }^{\text {F10 }}$ cells were dissociated with Accutase, suspended in medium, inoculated into 6-well plates (200 cells per well) in triplicate, and then incubated overnight. The cells were treated with various concentrations of drugs or with solvent (DMSO or water) as a negative control. After incubation for 10 days, cells were fixed with $4 \%$ formaldehyde solution and stained with $0.1 \%(w / v)$ crystal violet, and the number of colonies in each well was counted.

\subsection{Tumor Sphere Assay}

HCT116 and HCT116R ${ }^{\text {F10 }}$ cells were seeded into 96-well PrimeSurface ${ }^{\circledR}$ plate 96U (Sumitomo Bakelite Co., Ltd., Tokyo, Japan) plates (1000 cells per well) in triplicate and then treated with various concentrations of 5-FU or DMSO (as a negative control). Following incubation for 14 days, tumor sphere size was monitored once every 3-4 days. Tumor sphere volume $(V)$ was calculated using the following formula: $V=a b^{2} / 2$ ( $a$ and $b$ are the long and short diameters of the tumor sphere, respectively).

\subsection{Exome Sequencing Analysis}

DNA extraction was performed as previously described [29]. Genomic DNA was extracted from cells $\left(5 \times 10^{6}\right.$ cells) by using a DNeasy Tissue Kit (QIAGEN, Venlo, Netherlands), according to the manufacturer's instructions. Exome sequencing of parental HCT116 and 
HCT116R ${ }^{\mathrm{F} 10}$ cells was performed by APRO Life Science Institute, Inc. (Tokushima, Japan) and Macrogen Global Headquarters (Seoul, Korea).

\subsection{Western Blot Analysis}

Western blot analysis was performed as previously described [29,32-34]. The antibodies used were rabbit anti-thymidylate synthase (D5B3) monoclonal antibody (9045S, 1:1000, Cell Signaling Technologies, Danvers, MA, USA), mouse anti-DPYD (A-5) monoclonal antibody (sc-376712, 1:1000, Santa Cruz Biotechnology, Dallas, TX, USA), rabbit anti-GAPDH antibody (2275-PC-100, 1:20,000, Trevigen, Gaithersburg, MD, USA), mouse anti-beta-actin monoclonal antibody (A19178-200UL, 1:20,000, Sigma-Aldrich), horseradish peroxidaselinked anti-rabbit IgG (1:20,000, GE Healthcare, Pittsburgh, PA, USA), and horseradish peroxidase-linked whole antibody anti-mouse IgG (1:20,000, GE Healthcare).

\subsection{Statistical Analysis}

The data are presented as means \pm standard deviation. The significance of differences among groups was evaluated using a Student's $t$-test; $p<0.05$ was considered statistically significant.

Author Contributions: Conceptualization, A.S.; investigation, C.K., Y.O. and A.S.; writing—original draft preparation, A.S.; writing - review and editing, C.K., Y.O. and A.S.; visualization, C.K., Y.O. and A.S.; project administration, A.S. All authors have read and agreed to the published version of the manuscript.

Funding: This research received no external funding.

Institutional Review Board Statement: Not applicable.

Informed Consent Statement: Not applicable.

Data Availability Statement: Not applicable.

Acknowledgments: We thank Yusuke Wataya (Okayama University) for their helpful discussions.

Conflicts of Interest: The authors declare no conflict of interest.

\section{References}

1. Bray, F.; Ferlay, J.; Soerjomataram, I.; Siegel, R.L.; Torre, L.A.; Jemal, A. Global cancer statistics 2018: GLOBOCAN estimates of incidence and mortality worldwide for 36 cancers in 185 countries. CA Cancer J. Clin. 2018, 68, 394-424. [CrossRef] [PubMed]

2. Longley, D.B.; Harkin, D.P.; Johnston, P.G. 5-fluorouracil: Mechanisms of action and clinical strategies. Nat. Rev. Cancer 2003, 3, 330-338. [CrossRef] [PubMed]

3. Blondy, S.; David, V.; Verdier, M.; Mathonnet, M.; Perraud, A.; Christou, N. 5-Fluorouracil resistance mechanisms in colorectal cancer: From classical pathways to promising processes. Cancer Sci. 2020, 111, 3142-3154. [CrossRef] [PubMed]

4. Heidelberger, C. Fluorinated pyrimidines. Prog. Nucleic Acid. Res. Mol. Biol. 1965, 4, 1-50.

5. Santi, D.V. Perspective on the design and biochemical pharmacology of inhibitors of thymidylate synthetase. J. Med. Chem. 1980, 23, 103-111. [CrossRef]

6. Copur, S.; Aiba, K.; Drake, J.C.; Allegra, C.J.; Chu, E. Thymidylate synthase gene amplification in human colon cancer cell lines resistant to 5-fluorouracil. Biochem. Pharmacol. 1995, 49, 1419-1426. [CrossRef]

7. Johnston, P.G.; Lenz, H.J.; Leichman, C.G.; Danenberg, K.D.; Allegra, C.J.; Danenberg, P.V.; Leichman, L. Thymidylate synthase gene and protein expression correlate and are associated with response to 5-fluorouracil in human colorectal and gastric tumors. Cancer Res. 1995, 55, 1407-1412.

8. Wang, W.; Marsh, S.; Cassidy, J.; McLeod, H.L. Pharmacogenomic dissection of resistance to thymidylate synthase inhibitors. Cancer Res. 2001, 61, 5505-5510.

9. Popat, S.; Matakidou, A.; Houlston, R.S. Thymidylate synthase expression and prognosis in colorectal cancer: A systematic review and meta-analysis. J. Clin. Oncol. 2004, 22, 529-536. [CrossRef]

10. Ishibiki, Y.; Kitajima, M.; Sakamoto, K.; Tomiki, Y.; Sakamoto, S.; Kamano, T. Intratumoural thymidylate synthase and dihydropyrimidine dehydrogenase activities are good predictors of 5-fluorouracil sensitivity in colorectal cancer. J. Int. Med. Res. 2003, 31, 181-187. [CrossRef]

11. Zhang, N.; Yin, Y.; Xu, S.J.; Chen, W.S. 5-Fluorouracil: Mechanisms of resistance and reversal strategies. Molecules 2008, 13, 1551-1569. [CrossRef] [PubMed] 
12. Chu, E.; Koeller, D.M.; Johnston, P.G.; Zinn, S.; Allegra, C.J. Regulation of thymidylate synthase in human colon cancer cells treated with 5-fluorouracil and interferon-gamma. Mol. Pharmacol. 1993, 43, 527-533. [PubMed]

13. Drake, J.C.; Allegra, C.J.; Johnston, P.G. Immunological quantitation of thymidylate synthase-FdUMP-5,10-methylenetetrahydrofolate ternary complex with the monoclonal antibody TS 106. Anticancer Drugs 1993, 4, 431-435. [CrossRef] [PubMed]

14. Mori, R.; Futamura, M.; Tanahashi, T.; Tanaka, Y.; Matsuhashi, N.; Yamaguchi, K.; Yoshida, K. 5FU resistance caused by reduced fluoro-deoxyuridine monophosphate and its reversal using deoxyuridine. Oncol. Lett. 2017, 14, 3162-3168. [CrossRef]

15. Boyer, J.; McLean, E.G.; Aroori, S.; Wilson, P.; McCulla, A.; Carey, P.D.; Longley, D.B.; Johnston, P.G. Characterization of p53 wild-type and null isogenic colorectal cancer cell lines resistant to 5-fluorouracil, oxaliplatin, and irinotecan. Clin. Cancer Res. 2004, 10, 2158-2167. [CrossRef] [PubMed]

16. Laskin, J.D.; Evans, R.M.; Slocum, H.K.; Burke, D.; Hakala, M.T. Basis for natural variation in sensitivity to 5-fluorouracil in mouse and human cells in culture. Cancer Res. 1979, 39, 383-390.

17. Yoshioka, A.; Tanaka, S.; Hiraoka, O.; Koyama, Y.; Hirota, Y.; Ayusawa, D.; Seno, T.; Garrett, C.; Wataya, Y. Deoxyribonucleoside triphosphate imbalance. 5-Fluorodeoxyuridine-induced DNA double strand breaks in mouse FM3A cells and the mechanism of cell death. J. Biol. Chem. 1987, 262, 8235-8241. [CrossRef]

18. Yamada, M.; Nakagawa, H.; Fukushima, M.; Shimizu, K.; Hayakawa, T.; Ikenaka, K. In vitro study on intrathecal use of 5-fluoro-2'-deoxyuridine (FdUrd) for meningeal dissemination of malignant brain tumors. J. Neurooncol. 1998, 37, 115-121. [CrossRef]

19. Peters, G.J.; Backus, H.H.; Freemantle, S.; van Triest, B.; Codacci-Pisanelli, G.; van der Wilt, C.L.; Smid, K.; Lunec, J.; Calvert, A.H.; Marsh, S.; et al. Induction of thymidylate synthase as a 5-fluorouracil resistance mechanism. Biochim. Biophys. Acta 2002, 1587, 194-205. [CrossRef]

20. Chu, E.; Koeller, D.M.; Casey, J.L.; Drake, J.C.; Chabner, B.A.; Elwood, P.C.; Zinn, S.; Allegra, C.J. Autoregulation of human thymidylate synthase messenger RNA translation by thymidylate synthase. Proc. Natl. Acad. Sci. USA 1991, 88, 8977-8981. [CrossRef]

21. Chu, E.; Voeller, D.; Koeller, D.M.; Drake, J.C.; Takimoto, C.H.; Maley, G.F.; Maley, F.; Allegra, C.J. Identification of an RNA binding site for human thymidylate synthase. Proc. Natl. Acad. Sci. USA 1993, 90, 517-521. [CrossRef]

22. Keyomarsi, K.; Samet, J.; Molnar, G.; Pardee, A.B. The thymidylate synthase inhibitor, ICI D1694, overcomes translational detainment of the enzyme. J. Biol. Chem. 1993, 268, 15142-15149. [CrossRef]

23. Chu, E.; Allegra, C.J. The role of thymidylate synthase as an RNA binding protein. Bioessays 1996, 18, 191-198. [CrossRef]

24. Kitchens, M.E.; Forsthoefel, A.M.; Barbour, K.W.; Spencer, H.T.; Berger, F.G. Mechanisms of acquired resistance to thymidylate synthase inhibitors: The role of enzyme stability. Mol. Pharmacol. 1999, 56, 1063-1070. [CrossRef] [PubMed]

25. Kitchens, M.E.; Forsthoefel, A.M.; Rafique, Z.; Spencer, H.T.; Berger, F.G. Ligand-mediated induction of thymidylate synthase occurs by enzyme stabilization. Implications for autoregulation of translation. J. Biol. Chem. 1999, 274, 12544-12547. [CrossRef]

26. Marverti, G.; Ligabue, A.; Paglietti, G.; Corona, P.; Piras, S.; Vitale, G.; Guerrieri, D.; Luciani, R.; Costi, M.P.; Frassineti, C.; et al. Collateral sensitivity to novel thymidylate synthase inhibitors correlates with folate cycle enzymes impairment in cisplatinresistant human ovarian cancer cells. Eur. J. Pharmacol. 2009, 615, 17-26. [CrossRef]

27. Washtien, W.L. Increased levels of thymidylate synthetase in cells exposed to 5-fluorouracil. Mol. Pharmacol. 1984, 25, 171-177. [PubMed]

28. Mohsen, A.W.; Aull, J.L.; Payne, D.M.; Daron, H.H. Ligand-induced conformational changes of thymidylate synthase detected by limited proteolysis. Biochemistry 1995, 34, 1669-1677. [CrossRef] [PubMed]

29. Ogino, Y.; Sato, A.; Uchiumi, F.; Tanuma, S.I. Cross resistance to diverse anticancer nicotinamide phosphoribosyltransferase inhibitors induced by FK866 treatment. Oncotarget 2018, 9, 16451-16461. [CrossRef] [PubMed]

30. Ogino, Y.; Sato, A.; Uchiumi, F.; Tanuma, S.I. Genomic and tumor biological aspects of the anticancer nicotinamide phosphoribosyltransferase inhibitor FK866 in resistant human colorectal cancer cells. Genomics 2019, 111, 1889-1895. [CrossRef] [PubMed]

31. Inada, M.; Shindo, M.; Kobayashi, K.; Sato, A.; Yamamoto, Y.; Akasaki, Y.; Ichimura, K.; Tanuma, S.I. Anticancer effects of a non-narcotic opium alkaloid medicine, papaverine, in human glioblastoma cells. PLoS ONE 2019, 14, e0216358. [CrossRef] [PubMed]

32. Ogino, Y.; Sato, A.; Kawano, Y.; Aoyama, T.; Uchiumi, F.; Tanuma, S.I. Association of ABC Transporter With Resistance to FK866, a NAMPT Inhibitor, in Human Colorectal Cancer Cells. Anticancer Res. 2019, 39, 6457-6462. [CrossRef] [PubMed]

33. Sato, A.; Satake, A.; Hiramoto, A.; Wataya, Y.; Kim, H.S. Protein expression profiles of necrosis and apoptosis induced by 5-fluoro-2'-deoxyuridine in mouse cancer cells. J. Proteome Res. 2010, 9, 2329-2338. [CrossRef] [PubMed]

34. Sato, A.; Nakama, K.; Watanabe, H.; Satake, A.; Yamamoto, A.; Omi, T.; Hiramoto, A.; Masutani, M.; Wataya, Y.; Kim, H.S. Role of activating transcription factor 3 protein ATF3 in necrosis and apoptosis induced by 5-fluoro-2' -deoxyuridine. FEBS J. 2014, 281, 1892-1900. [CrossRef] [PubMed] 